
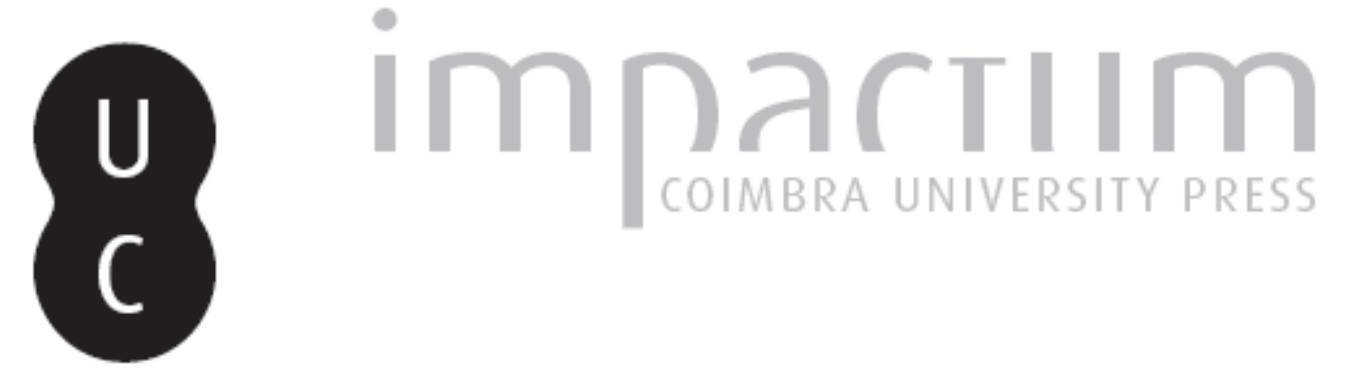

\title{
Anatomia do comentário: corrupção, noticiários e destinatários
}

Autor(es): $\quad$ Figueiras, Rita

Publicado por: Imprensa da Universidade de Coimbra

URL persistente:

URI:http://hdl.handle.net/10316.2/36967

DOI:

DOI:http://dx.doi.org/10.14195/2183-5462_26_7

Accessed : $\quad$ 26-Apr-2023 09:05:39

A navegação consulta e descarregamento dos títulos inseridos nas Bibliotecas Digitais UC Digitalis, UC Pombalina e UC Impactum, pressupõem a aceitação plena e sem reservas dos Termos e Condições de Uso destas Bibliotecas Digitais, disponíveis em https://digitalis.uc.pt/pt-pt/termos.

Conforme exposto nos referidos Termos e Condições de Uso, o descarregamento de títulos de acesso restrito requer uma licença válida de autorização devendo o utilizador aceder ao(s) documento(s) a partir de um endereço de IP da instituição detentora da supramencionada licença.

Ao utilizador é apenas permitido o descarregamento para uso pessoal, pelo que o emprego do(s) título(s) descarregado(s) para outro fim, designadamente comercial, carece de autorização do respetivo autor ou editor da obra.

Na medida em que todas as obras da UC Digitalis se encontram protegidas pelo Código do Direito de Autor e Direitos Conexos e demais legislação aplicável, toda a cópia, parcial ou total, deste documento, nos casos em que é legalmente admitida, deverá conter ou fazer-se acompanhar por este aviso.

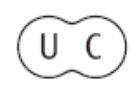




\section{Media Jornalismo}

\section{CORRUPÇÃO POLÍTICA, MEDIA E DEMOCRACIA}




\title{
ANATOMIA DO COMENTÁRIO: CORRUPÇÃO, NOTICIÁRIOS E DESTINATÁRIOS \\ COMMENT'S ANATOMY: \\ CORRUPTION, NEWSCASTS AND AUDIENCE
}

\section{RITA FIGUEIRAS}

RITAFIGUEIRAS@FCH.LISBOA.UCP.PT

\begin{abstract}
Resumo
No âmbito dos estudos sobre a corrupção e os media, este estudo tem dois grandes objetivos: identificar o modo como os comentadores nos noticiários da televisão generalista abordam dois dos casos de corrupção mais mediatizados nos últimos anos em Portugal (os casos Freeporte Face Oculta), relacionando as narrativas jornalísticas e as dos comentários, e conhecer a forma como os comentadores se posicionam no debate público e entendem a sua função no processo comunicativo democrático. Para os comentadores os casos foram mais sobre estratégia e desempenho dos atores e das instituições envolvidas do que sobre o crime da corrupção. A definição dos problemas, as interpretações causais e recomendações foram construídas a partir do establishment, onde os conflitos internos dentro de cada uma das esferas implicadas nos casos, e entre as várias esferas, foram transpostos para os comentários; ainda que alguns comentadores tenham articulado o processo horizontal de comunicação intra, e interelite, e o vertical dirigido ao público em geral. 0 estudo de ambos os casos permitiu verificar que o espaço de opinião continua a subsistir como um setor dominado pelas elites dirigentes na sociedade portuguesa, que comunica principalmente para si própria e que se mantém com uma capacidade elevada de imunidade à evolução do contexto social e mediático. A análise da narrativa do comentário revelou-se, assim, um local privilegiado para identificar e compreender como as lutas sociais de poder são travadas no espaço público.
\end{abstract}

\section{Palavras-chave}

Comentadores, Espaço de Opinião, Mediação, Elites, Corrupção, Televisão Generalista, Noticiário Televisivo.

\section{AbStract}

Within corruption and media studies, this research study aims at identifying how television pundits comment on two of the most mediatized corruption cases of the past years (Freeportand Face Oculta), relating both news and opinion narratives, and acknowledging who is pundits imagined audience and how they position themselves in the democratic communicative process. Actors and institutions related with both cases were mainly debated from a strategy and performance angle; the definition of problems, explanations and recommendations were built from the establishment point of view, where inner conflicts and conflicts between different fields of power involved in both cases were also evident in the opinion sphere; whereas some 
pundits have articulated the intra and inter-elite horizontal communication process together with the vertical communication process, comprising the general audience, this research study concluded that the opinion space it still a sector dominated by the traditional Portuguese elite, who communicates mostly to its inner circle, which means that this sector keeps a high level of immunity to social and media change. Analyzing both pundits narrative and rhetoric style also allowed one to understand better how power struggles are performed in the Portuguese public sphere.

Keywords

Pundits, Opinion Space, Mediation, Elites, Corruption, Free-to-air television, Television newscasts. 


\section{ANATOMIA DO COMENTÁRIO: CORRUPÇÃO, NOTICIÁRIOS E DESTINATÁRIOS ${ }^{10}$ \\ COMMENT'S ANATOMY: \\ CORRUPTION, NEWSCASTS AND AUDIENCE}

\section{RITA FIGUEIRAS | FACULDADE DE CIÊNCIAS HUMANAS}

DA UNIVERSIDADE CATÓLICA PORTUGUESA

RITAFIGUEIRAS@FCH.LISBOA.UCP.PT

Na sociedade ocidental o crime de corrupção é consensualmente visto como uma das ameaças mais perigosas para os regimes democráticos. 0 abuso do poder (delegado) para ganhos privados, que caracteriza este tipo de crime (International Transparency, 2010: xxvi), cria distorção nos mercados e iniquidade nas sociedades. Os negócios corruptos causam, assim, múltiplos danos económicos e minam os princípios que estão no âmago dos valores democráticos (Heidenheimer \& Johnston: 2002; Thompson: 2000; Granovetter: 2004).

Este é um crime complexo que tende a articular diferentes campos de poder, como a política (mau uso ou abuso de poder), a economia (infração de leis que regulam a aquisição e gestão de recursos económicos), a justiça (a moldura legal) e os media (revelação de informações) (Blankenburg: 2002). No entanto, a intensificação dos processos de globalização e a crescente transição dos poderes de decisão de âmbito nacional para instituições supranacionais têm produzido novos níveis de complexidade na configuração geopolítica da corrupção. Este crime deixou, assim, de estar exclusivamente relacionado com a gestão local ou nacional de interesses para se tornar dependente de redes internacionais de clientelismo político. Numa outra perspetiva, a complexidade da corrupção deriva do seu caráter invisível e silencioso (Tumber \& Waisbord: 2004). Apenas quem conhece bem as práticas e rotinas de uma determinada instituição é capaz de detetar ilegalidades quando elas ocorrem (Shea: 2009). Todavia, quem as identifica tende a considerar que as condições adequadas para denunciar estes crimes nunca estão reunidas, o que significa que quem observa e discorda das ilegalidades praticadas acaba por reforçar a invisibilidade e a espiral do silêncio em torno deste tipo de condutas.

Neste contexto, os media desempenham um papel fundamental na revelação de dados relacionados com casos de corrupção, mas não o fazem sozinhos. Num estudo de 2002, Erhard Blankenburg identificou uma aliança entre juízes e jornalistas com o objetivo de divulgarem informações cuidadosamente selecionadas e que alimentavam a presença de determinados casos de corrupção nos media. Deste modo, a perceção que o público tem deste tipo de crimes é fortemente estruturada pela cobertura noticiosa, que tende a descontextuali-

10 Este artigo foi realizado no âmbito do projeto FCT (PTDC/IVC-COM/5244/2012), Corrupção Política nos Media: Uma Perspectiva Comparada, sob a coordenação de Isabel Ferin Cunha e sediado no Centro de Investigação Media e Jornalismo (CIMJ). 
zar e a dramatizar os casos, enfatizando determinados factos em detrimento de outros e ordenando-os em benefício de uma narrativa apelativa (Blankenburg: 2002). Esta cobertura é, assim, produto da lógica comercial e concorrencial que transformou 0 setor dos media numa indústria baseada no escândalo ${ }^{11}$, mas é igualmente um produto da luta entre opositores políticos partidários e não- partidários e da necessidade que os jornalistas têm de demonstrar que estão a cumprir a sua função política de vigilância e denúncia dos abusos de poder (Thompson: 2000).

Neste processo, a par das notícias, os comentários também desempenham um papel relevante na construção da perceção pública sobre a corrupção política. Os comentadores fazem parte do conjunto de atores que, numa hierarquia de influências e relações distintas, contribuem para a configuração dos temas em circulação nos media e para moldar a perceção dos cidadãos.

Se no âmbito dos estudos sobre a corrupção existem poucos trabalhos acerca da cobertura jornalística deste tipo de crime, relativamente à forma como os comentadores abordam 0 tema conhecem-se ainda menos pesquisas. Este artigo pretende contribuir para colmatar esta falha e, ao mesmo tempo, fornecer novos dados para 0 aprofundamento dos estudos sobre 0 espaço de opinião e os comentadores. 0 estudo que aqui se apresenta tem, assim, dois grandes objetivos: (1) identificar 0 modo como os comentadores abordam dois dos casos de corrupção mais mediatizados nos últimos anos em Portugal (os casos Freeport e Face Oculta), relacionando as narrativas jornalísticas e as dos comentários sobre os dois casos e (2) conhecer a forma como os comentadores se posicionam no debate público e entendem a sua função no processo comunicativo democrático. Estes objetivos decorrem da assunção de que o comentário tem uma conexão com as notícias, porque parte delas para debater os assuntos em agenda, e uma relação forte com as esferas de decisão da sociedade. Por um lado, porque a maioria dos comentadores provém dessas mesmas esferas e, por outro, porque esses campos de poder, e os seus protagonistas, são os temas mais debatidos pelos comentadores políticos (Figueiras: 2005; 2007; 2009; 2011; 2015). 0 espaço de opinião é, portanto, um interface do e de poder ao permitir a uma certa elite ganhar visibilidade e influência acrescidas na sociedade portuguesa através dos media. Com este estudo pretendemos então contribuir para um meIhor conhecimento acerca da forma como os comentadores entendem e usam o seu poder no espaço público.

\section{Espaço Opinião, os Comentadores e o Processo Comunicativo Democrático}

Na retórica cultural das sociedades ocidentais, a esfera pública ocupa um lugar central na mediação social, e é nela que a sociedade discute questões públicas e

11 Para além da componente comercial, a crescente presença dos escândalos nas sociedades ocidentais tem as suas raízes na transformação que os media operaram na visibilidade pública (Thompson: 2000: 261), em consequência do declínio das ideologias, da regulamentação jurídica da vida política e da emergência da "política de confiança" - ou seja, a partir do momento em que o discurso político passou a colocar a ênfase não em projetos e questões ideológico-partidárias, mas no carácter e na credibilidade dos políticos. Desde então, a exposição pública tem-nos tornado vulneráveis a qualquer tipo de publicidade negativa e os escândalos alimentam-se de um dos bens simbólicos mais relevantes para qualquer indivíduo: a sua reputação. 
que a opinião pública - considerada o principal motor da política democrática - é construída através de um processo contínuo de tensões e negociações. Deste modo, a mediação, ou seja "qualquer ato de intervenção, transmissão ou reconciliação entre diferentes intervenientes, individuais, coletivos ou institucionais" (Mazzoleni \& Schultz: 1999: 249), pode ser entendida como uma ferramenta político-cultural basilar no debate público em geral, mas também em cada um dos seus níveis constitutivos que englobam a produção, a representação e a receção dos temas debatidos pelos media.

Este entendimento reflete a tradição intelectual europeia dominante e está na base das teorias "racional-iluministas" que encontram eco nas teses de Jürgen Habermas e naqueles inspirados por elas (Habermas: 1984; Fraser: 2007; Luhmann: 1993; Schudson: 1995). Esta conceção está também na base dos primeiros projetos democráticos, a partir dos finais do século XVIII, altura em que a imprensa passou a ser entendida como uma instituição democrática e um elemento fundamental da esfera pública, na dupla condição de elemento constitutivo do debate público e de objeto de discussão (Habermas: 1984). A imprensa assumiu, assim, um papel fundamental no processo de democratização das sociedades modernas, nomeadamente na socialização dos novos valores e padrões de comunicação, que podem ser sintetizados na promoção de uma cultura de debate público (Habermas: 1984; Thompson: 1998). Esta função também produziu impacto sobre as primeiras experiências de governos democráticos, que tiveram de aprender a lidar com a imprensa como um agente questionador e crítico da sua atuação, forçando os líderes políticos a tornarem-se mais abertos à crítica e atentos à opinião pública. A imprensa foi-se então definindo em torno de um conjunto de prorrogativas políticas que podem ser sintetizadas em três grandes funções: como um fórum cívico (para informar, explicar e promover o debate sobre questões públicas); como um agente de fiscalização (para monitorar os abusos de poder); e como um agente mobilizador (envolver os cidadãos no processo político) (Norris, 2000: 22-35).

Neste contexto, o espaço de opinião tornou-se um elemento constitutivo do processo comunicativo democrático (Nimmo \& Combs: 1994; Jacobs \& Townsley: 2011), e, em linha com o cascading activation mode/ de Robert Entman (2003), podemos considerar que os comentadores desempenham um papel relevante na ativação da atenção e na formação da opinião pública, num processo que combina mecanismos de agenda-setting (definição da agenda pública), priming (grau de destaque dado aos temas), framing (enquadramento dado aos temas) e feedback (reação aos temas pela sociedade). Os comentadores fazem parte do conjunto de atores que, numa hierarquia de influências e relações distintas, condicionam o desenrolar dos temas no espaço público e contribuem para moldar a perceção que os cidadãos têm sobre variados temas na sociedade.

Todavia, um conjunto de padrões distintos de desenvolvimento relacionados com 0 estado, o sistema dos partidos políticos, o padrão das relações entre interesses económicos e políticos e o desenvolvimento da sociedade civil, entre outros elementos da estrutura social (Hallin \& Mancini: 2004), fizeram emergir na sociedade ocidental modelos de democracia e de sistemas de media distintos que, por sua vez, produziram diferentes conceções de espaço de opinião e diversos níveis de envolvimento das elites e dos cidadãos no processo comunicativo democrático. 
Estas conceções oscilam entre um entendimento do espaço público e do espaço de opinião como um lugar onde as elites participam num processo horizontal de comunicação que perspetiva a política como um jogo que inclui apenas os seus insiders (que pode ser condensada nas teses luhmanianas) e, no outro extremo, um entendimento do espaço público e o espaço opinião como lugares de mediação alargada entre as elites e a sociedade, promovendo uma discussão que engloba os cidadãos no debate público (que podem ser tipificadas nas teses haberrmasianas). A maioria das sociedades ocidentais situa-se entre os dois espectros e com a análise dos casos Freeport e Face Oculta pretendemos extrair um conjunto de pistas que contribuam para pensarmos o caso português.

Ao longo dos últimos anos, o mercado do comentário em Portugal tem-se expandido, refletindo a valorização dada à opinião, ao debate e à discussão no quadro da sociedade democrática (Habermas: 1984), mas tem-se expandido também por motivos comerciais, patentes nas estratégias de recrutamento de rostos conhecidos do grande público e na disputa desses mesmos rostos pelos variados media, nomeadamente pelos canais de televisão. 0 recurso a opiniões especializadas ou credenciadas na sociedade portuguesa tem feito com que, por um lado, aumente a quantidade de comentadores nos diversos media e, por outro, os comentadores de referência acumulem e/ou transitem de media, permanecendo sempre no espaço público (Figueiras: 2005; 2007; 2009; 2011).

Na televisão, o comentário tem ganho crescente protagonismo e tornou-se uma rubrica estruturante das emissões dos canais de televisão generalistas portugueses. A contratação de Marcelo Rebelo de Sousa pela TVI, em 2000, colocou a figura do comentador na sociedade portuguesa num patamar totalmente novo. A entrada do comentário nos noticiários dirigidos ao grande público democratizou o acesso à opinião esclarecida e massificou o consumo de um produto que era tradicionalmente dirigido ao público mais esclarecido (a opinião pública dirigente) e consumidor da imprensa de referência (Figueiras: 2009).

0 destaque dado à opinião nos jornais televisivos de elevada audiência tem conferido, assim, uma grande visibilidade ao comentário e a alguns comentadores em particular, que desempenham um papel relevante no processo de construção dos temas públicos e na formação da opinião, passando também o espaço de opinião a fazer parte da estratégia de comunicação dos partidos políticos. Na televisão portuguesa é notória a crescente divisão do espaço de opinião entre os partidos de governo (nos canais de televisão generalistas) e dos partidos com assento parlamentar (nos canais de notícias por cabo), verificando-se um processo de lottizzazione partidária do espaço público (Mancini: 2009). Esta compartimentação do comentário é uma manifestação de redes clientelares ou de uma partidocracia, mais evidente nas democracias do sul da Europa, revelando uma certa forma de divisão do poder no espaço público. Deste modo, como interface do e de poder, o espaço de comentário apresenta-se como um lugar privilegiado de análise de uma das instâncias que é, simultaneamente, central na formação da opinião pública e na representação das esferas de poder. Esta é assim uma oportunidade para conhecer como os comentadores se posicionaram face a dois escândalos de poder, como são os crimes de corrupção associados aos casos Freeport e Face Oculta, e como se posicionam no processo comunicativo democrático. 
Metodologia

Neste estudo, a unidade de contexto da análise são os noticiários televisivos de prime-time (20 horas) dos canais generalistas portugueses: o Telejornal da RTP1, 0 Jornal da Noite da SIC e o Jornal Nacional/Jornal de Sexta da TVI. A unidade de registo é composta pelos segmentos de comentário e o período temporal de análise incide sobre todos os comentários emitidos nos noticiários em 2009, ano em que os casos Freeporte Face Oculta tiveram maior incidência nos media nacionais.

0 estudo combina três níveis de análise: (1) relação entre as narrativas jornalísticas e dos comentários; (2) estilo dos comentários e (3) posicionamento dos comentadores no processo comunicativo democrático. Para levar a cabo o primeiro objetivo do estudo, utilizamos as categorias aplicadas na análise dos textos noticiosos sobre os casos Freeporte Face Oculta (Cunha: 2014: 371-419): temas, atores e tom (modalidades: negativo, equilibrado, neutro e positivo). Com o objetivo de explorar as complexidades, nuances e camadas contidas nos comentários, analisamos o estilo das opiniões a partir de um conjunto de indicadores sistematizados em estudos realizados sobre os comentadores (Figueiras: 2009; Jacobs \& Townsley: 2011). Para tal, construímos quatro modalidades: "analítico-interpretativo/explicativo" (explicação do contexto e consequências, bem como as relações entre os elementos que enformam temas, decisões ou escolhas); "tomada de posição" (argumentação de apoio ou crítica, sendo a opinião apresentada num formato a favor ou contra); "reenquadramento" (convite a reexaminar premissas básicas e/ ou tentativa de reorientar a atenção para outras dimensões da questão em análise); "informativo" (apresentação de novos factos, dados e elementos). A distinção analítica entre os indicadores nem sempre é fácil e simples e, por vezes, há intervenções que congregam vários, sendo isso evidente nos excertos apresentados neste estudo. Todavia, é possível identificar um estilo dominante para mapear a distribuição de estilos de comentário.

Por forma a cumprirmos o terceiro objetivo do estudo e conhecermos como é que os comentadores se posicionam no processo comunicativo democrático, sinalizamos as marcas discursivas que nos permitem identificar a que audiências é que os comentadores se dirigem. Genericamente, dirigem-se a dois tipos distintos: redes de elites políticas e público em geral. Deste modo, a primeira distinção a fazer é entre os autores de opinião que se posicionam como estando comprometidos numa discussão dirigida a insiders políticos e os que têm primordialmente em vista uma audiência vasta de cidadãos, integrando os outsiders no seu comentário.

Este estudo combina, assim, 0 uso de metodologias quantitativas e qualitativas de análise. Com a utilização de metodologias quantitativas pretende-se identificar a frequência dos temas, os atores e os tons que os comentadores associam à corrupção. Este procedimento tem como objetivo aprofundar o conhecimento sobre a produção de comentários acerca da corrupção, aferir as valorações produzidas, bem como os agentes e as instituições envolvidas. Na perspetiva qualitativa pretende-se proceder à análise do estilo retórico dos comentadores e das marcas de destinatários presentes no seu discurso, ou seja, quem definem como auditório dos seus comentários. Estes elementos também nos permitirão conhecer de que forma os comentadores se posicionam no processo comunicativo democrático em Portugal. 


\section{A Corrupção no Comentário Televisivo}

Nos últimos anos tem-se assistido a um elevado investimento no comentário e uma grande circulação de comentadores entre diferentes espaços de opinião em diversos media, confirmando o dinamismo endogâmico do espaço de opinião em Portugal, há muito referenciado em estudos sobre o tema (Figueiras: 2005). Se em 2015 todos os noticiários de prime-time dos canais generalistas contam com a colaboração de um comentador residente num dia fixo da semana, em 2009 o panorama era já idêntico, com exceção da SIC que, à época, não recorria a comentadores fixos no seu noticiário. Nesse ano encontrávamos Marcelo Rebelo de Sousa num espaço de opinião acoplado ao noticiário de Domingo da RTP1, e Miguel Sousa Tavares e Vasco Pulido Valente no noticiário da noite na TVI. Todavia, este último deixou de colaborar com o canal de Queluz na sequência do cancelamento do Jornal de Sexta conduzido por Manuel Moura Guedes, em setembro de 2009.

Os casos Freeport e Face Oculta foram ambos comentados nos noticiários de prime-time dos três canais de televisão generalistas. 0 quadro 1 (em anexo) dá-nos informações relativas aos comentadores que opinaram sobre os casos em análise, ao seu perfil e ao número de vezes os comentaram.

Em termos de atenção concedida a cada tema é notório que o caso Freeport foi objeto de mais comentários do que o caso Face Oculta: 32 e 11 comentários, respetivamente. Independentemente da substância, há outros fatores que ajudam a contextualizar a disparidade entre a quantidade de comentários produzidos para cada um dos casos em análise. Por um lado importa considerar a cronologia dos eventos. 0 caso Freeport foi espoletado em 2005: envolvendo o Primeiro-Ministro da época, José Sócrates, o tema permaneceu na agenda pública ao longo de vários anos, inclusive em 2009, ano de eleições legislativas. Por sua vez, o caso Face Oculta só irrompeu no espaço público no fim de outubro desse ano. Por outro lado, convém ter presente que a alteração editorial verificada na TVI, com a saída de Manuela Moura Guedes, também produziu consequências, uma vez que a saída da jornalista contribuiu para a diminuição da presença do caso Freeport na agenda noticiosa do canal de televisão.

No contexto atual, qualquer escândalo político é o produto da interação entre 0 campo político, judicial e mediático (Thompson: 2000). Se atentarmos no perfil dos comentadores que produziram opinião sobre os casos em análise, sendo isto ainda mais evidente nos comentadores que se debruçaram sobre o caso Freeport (pela quantidade de opiniões produzidas), verificamos que a maioria provém exatamente destes três campos de poder, notando-se uma presença residual de académicos, mas que têm ou tiveram ligações a pelo menos uma das esferas referidas. Isto significa que o comentário produzido se cingiu a interpretações feitas a partir de cada uma dessas esferas de poder e que para o espaço de comentário foram transpostas as lutas internas de cada uma dessas esferas e os conflitos entre os vários campos implicados. Significa também que o comentário circunscreveu as perspetivas aos interesses dos campos envolvidos, tendo sido excluídos outros ângulos de leitura sobre os casos. 0 comentário dos noticiários televisivos não contou com a presença de argumentos de vozes alternativas externas aos campos implicados, como especialistas em corrupção, por exemplo.

Depois desta análise introdutória, vamos centramo-nos em cada um dos casos em particular para, mais à frente neste texto, regressarmos a uma análise de con- 
junto sobre o posicionamento dos comentadores no processo comunicativo democrático, que consubstancia o terceiro objetivo do estudo.

\section{CASO FREEPORT}

0 processo Freeport teve na sua origem suspeitas de corrupção (ativa e passiva) e tráfico de influências na alteração à Zona de Proteção Especial do Estuário do Tejo, no licenciamento do espaço comercial de Alcochete, quando José Sócrates era Ministro do Ambiente. A estes indícios juntaram-se outros de branqueamento de capitais e financiamento ilegal de partidos políticos.

0 caso começou a ser mediatizado nas vésperas das eleições legislativas de fevereiro de 2005, tornando-se José Sócrates - que era cabeça de lista pelo PS a essas eleições - um dos suspeitos de corrupção devido a ter subscrito o decreto-lei que aprovara a construção do outlet Freeport em Alcochete. 0 ex-Primeiro-Ministro não chegou, todavia, a ser ouvido na investigação do Departamento Central de Investigação e Ação Penal (DCIAP), mas o tribunal considerou que do julgamento resultaram fortes indícios de que existiram pagamentos dentro do Ministério do Ambiente e da Administração Pública, tendo por base os depoimentos de três testemunhas que referiram que o então Ministro do Ambiente José Sócrates recebera pagamentos em dinheiro para viabilizar o projeto. Todavia, até hoje 0 inquérito não resultou em nenhuma acusação, e o processo culminou na absolvição, em 2012, dos dois arguidos, Manuel Pedro e Charles Smith, da prática do crime de tentativa de extorsão aos promotores do centro comercial Freeport.

Ainda que o caso tenha sido noticiado pela primeira vez em 2005, foi apenas quando José Sócrates se recandidatou nas eleições legislativas de 2009 que ele teve maior projeção mediática. Como antecâmara da análise da opinião sobre 0 caso Freeport, e de modo a podermos relacionar as narrativas do comentário e noticiosa, começamos por identificar os temas principais, os atores mais referidos e o tom dominante nas peças jornalísticas.

Das 974 peças jornalísticas emitidas, 721 (74\%) foram em 2009 (Cunha: 2014: 371-419). Ao longo de todo esse ano o caso dominou a agenda político-mediática com 247 peças na TVI, 270 na SIC e 204 na RTP1. Os temas mais noticiados foram as declarações dos principais intervenientes (186 peças), as investigações e buscas do Ministério Público (70 peças) e o Caso Eurojust (55 peças). 0 tom que claramente se destacou foi o neutro (503 peças), seguido de uma cobertura negativa (131 peças) e equilibrada (40 peças). Os atores principais foram o Primeiro-Ministro José Sócrates (136 peças), o Presidente do Eurojust Lopes da Mota (63 peças), e o Procurador-Geral da República António Pinto Monteiro (53 peças). Numa associação entre ator principal e tom, verificamos que José Sócrates foi abordado maioritariamente de forma neutra ( 85 peças), seguido de um enfoque tendencialmente negativo (42 peças), tal como Lopes da Mota, Presidente do Eurojust, cuja cobertura foi maioritariamente neutra (40 peças), seguida de negativa (20 peças). Na maioria das peças sobre o PGR predominou também um tom neutro (41 peças), contra seis num tom tendencialmente negativo e outras seis num tom equilibrado.

Este foi também 0 ano em que o caso foi mais discutido nos espaços de comentário, e o Quadro, em anexo, ajuda-nos a compreender o uso estratégico da 
opinião sobre o caso Freeport nos jornais da televisão generalista. Nos noticiários de prime-time essa opinião apresentou-se sob a forma de três modalidades: como um tema da agenda dos comentadores fixos, como uma forma de complementar a abordagem noticiosa, e como uma estratégia comercial e simbólica dos grupos de comunicação. Na primeira modalidade, encontramos Marcelo Rebelo de Sousa (RTP1), Miguel Sousa Tavares e Vasco Pulido Valente, ambos na TVI. Na segunda, Eduardo Dâmaso (RTP1), António José Teixeira, José Gomes Ferreira, Ricardo Costa, Luís Filipe Carvalho (SIC) e Rogério Alves (SIC e TVI). Encontramos a terceira modalidade em duas vezes apenas, na SIC e na TVI, onde em ambos os noticiários foram emitidas peças curtas com opiniões produzidas em programas de comentário nos canais de informação no cabo que pertencem aos mesmos grupos de comunicação: "Quadratura do Círculo" na SIC Notícias e "A Torto e a Direito" na TVI24. Ao mesmo tempo que estas opiniões ajudavam a reforçar uma determinada proposta de leitura sobre os casos, permitiam diversificar a abordagem jornalística nos noticiários televisivos e promover programas de nicho emitidos nos canais de cabo junto dos auditórios mais vastos dos canais generalistas dos grupos. Esta estratégia foi igualmente reveladora dos fluxos de conteúdos em circulação dentro dos grupos de media. Este uso estratégico da opinião reforçou ainda a legitimidade simbólica dos comentadores de cada estação. 0 espaço de opinião é, já por si, uma instância de legitimação discursiva, pelo que este tipo de intertextualidade e recontextualização contribui para reforçar o estatuto de comentador e para o que Pierre Bourdieu (1989; 1997) definiu como o "círculo encantado da legitimação". A citação adquire assim os contornos de uma instância de legitimação discursiva de segundo grau.

Os tópicos foram debatidos com níveis de complexidade distintos dependendo do comentador em específico e o formato que enquadrou as suas possibilidades de expressão: poucos minutos no noticiário, partilha da análise com outros comentadores em estúdio ou o controlo do tempo dedicado ao caso em espaço de opinião em nome próprio.

Integradas nas 721 peças emitidas pelos canais de televisão, encontramos então 32 comentários sobre o caso Freeport assim repartidos: 10 na RTP1, 10 na SIC e 12 na TVI, correspondendo a um total de duas horas, seis minutos e cinquenta e seis segundos de opiniões emitidas nos noticiários de prime-time das televisões generalistas portuguesas. 0 caso foi amplamente comentado no espaço de opinião entre janeiro e maio de 2009. Durante estes cinco meses foram produzidos 30 dos 32 comentários sobre o processo em análise, significando também que o tema foi objeto regular de atenção, numa média de duas opiniões por semana. Os outros dois comentários foram feitos aquando do espoletar do caso Face Oculta.

De que modo é que os comentadores abordaram o caso Freeport? Em primeiro lugar, importa analisar os comentários em termos de temas, atores e tom, para, de seguida, extrairmos ilações sobre a relação entre os espaços de comentário e noticioso. Houve três grandes temas que se destacaram nos comentários no âmbito do caso Freeport. Investigações sobre Licenciamento/Corrupção (10 comentários), Conduta de José Sócrates (10 comentários) e Conduta da Justiça (sete comentários). Relacionado com o primeiro tema, debateram-se questões como procedimentos de licenciamento, práticas lícitas e ilícitas de aprovação de negócios, e dúvidas sobre eventuais envolvidos no caso. As palavras de Vasco Pulido Valente (TVI: 22.05.2009) 
ilustram bem a tendência dominante: "as pessoas não são claras quanto aos seus atos. Continua a haver aqui uma série de ambiguidades. Deveria haver maior clareza e há a maior confusão que inspira a maior desconfiança a toda a gente". Neste âmbito foram ainda vastamente analisadas as diferenças entre as molduras legais portuguesa e inglesa.

As reações de José Sócrates à cobertura jornalística do seu envolvimento no caso e ao que entendeu ser uma estratégia política para o derrubar foram dimensões do outro tema mais focado pelos comentadores, bem ilustrado no comentário de José Pacheco Pereira (SIC: 02.02.2009): "um Primeiro-Ministro não pode dizer isto sem dizer mais alguma coisa (...). Estou a ver um homem que tem um comportamento, face à verdade, elástico".

Em terceiro lugar debateu-se o Ministério Público, nomeadamente, putativos usos, interesses e objetivos políticos dos magistrados no caso, bem como declarações e atitudes das altas figuras do aparelho judicial, reveladoras das tensões internas nos campos sociais envolvidos. No entender de Marcelo Rebelo de Sousa (RTP1: 01.02.2009): "A investigação deve avançar, portanto, os investigadores, em vez de darem tantas entrevistas, devem trabalhar. 0 importante é que a Cândida Almeida chegue rapidamente a conclusões (...). E que se apure rapidamente isto". De forma complementar, o jurista e ex-Bastonário da Ordem dos Advogados Rogério Alves (TVI: 29.03.2009) afirmava que: "as autoridades não podem fingir que não conhecem as provas. 0 Ministério Público tem aqui uma obrigação especial de imprimir aceleração a este processo e chegar rapidamente a uma conclusão. (...). Há um dever quase patriótico de concluir esta investigação".

0 tom dominante foi o negativo, com 13 comentários. Os atores mais comentados foram José Sócrates (18 citações), seguido de António Pinto Monteiro, (9 citações) e Lopes da Mota e Cândida Almeida, ambos citados quatro vezes. No cruzamento das variáveis, verificamos que a apreciação geral destes atores foi predominantemente negativa. José Sócrates teve nove comentários negativos, contra cinco positivos, o Procurador-Geral da República teve cinco negativos e dois equilibrados, enquanto Lopes da Mota contou com dois negativos e Cândida Almeida, três negativos e um equilibrado. Estas variações decorreram do facto de as opiniões oscilarem entre uma certa cautela decorrente da escassez de dados concretos e de informação confirmada sobre o caso e das tomadas de posição contra a conduta das individualidades envolvidas, questão central na agenda do comentário sobre o caso Freeport.

As narrativas jornalísticas e a de opinião obedecem a lógicas particulares ainda que haja uma contiguidade entre ambas. A primeira está subordinada a uma lógica de informar o cidadão, enquanto a segunda pressupõe um espaço de exposição de ideias suscitadas a propósito das notícias do dia ou da semana. Verificamos que nos comentários sobre este caso as notícias foram um expectável ponto de partida. A contiguidade confirmou-se na agenda do comentário, cada vez mais presentificada e com os acontecimentos do dia e da semana a darem o mote para a análise dos temas. Todavia, a opinião não trabalha diretamente sobre factos, mas comenta a partir deles. No contexto do noticiário, os comentários sobre o caso Freeport, por um lado, particularizaram determinadas questões - como o comportamento de intervenientes concretos - e, por outro, extrapolaram para questões mais amplas, 
como a relação entre os negócios e a política. 0 destaque dado ao caso Eurojust é um bom exemplo disto mesmo. Na narrativa noticiosa, emergiu do caso Freeport, enquanto na narrativa da opinião não ganhou verdadeiro protagonismo por si só, sendo abordado de forma integrada nas apreciações sobre a atuação de figuras de proa de instituições-chave no caso ou como exemplo de redes informais de interesses instituídos. A nota diferenciadora de fundo registou-se no cruzamento das variáveis "atores" e "tom". Os comentadores foram muito mais críticos e negativos para com José Sócrates, Pinto Monteiro e Lopes da Mota do que as peças noticiosas que se mantiveram maioritariamente neutras face a estas personalidades.

Em termos da tradição cultural ocidental, o comentário foi instituído como um espaço de mediação, como um lugar de esclarecimento das questões em destaque nos media. Deste modo, importa saber como é que os comentadores debateram este caso e perceber se a narrativa da opinião se constituiu como um elemento passível de contribuir para clarificar a opinião pública. Ou seja, importa saber como é que os comentadores argumentaram acerca do Freeport.

A maioria dos comentadores tomou uma posição face ao caso (17 comentários, contra seis, apenas, do estilo informativo). A tomada de posição foi maioritariamente contra a forma como o Primeiro-Ministro, por um lado, e o Ministério Público, por outro, lidaram com 0 assunto. De entre os variados comentadores que se posicionaram contra a conduta de José Sócrates, destaca-se Vasco Pulido Valente (TVI, 23.01.2009): "O Primeiro-Ministro não pode pôr em causa a Procuradoria-Geral da República, o juiz de instrução e a polícia. 0 que ele insinuou que está por detrás disto é a velha cabala. (...) Que isso seja dito por um deputado, vá lá, que seja dito por um militante, até se desculpa, agora ser dito pelo Primeiro-Ministro, porque ele esquece-se que é Primeiro-Ministro e os Primeiros-Ministros não podem dizer certas coisas (...). Um Primeiro-Ministro não pode dizer estas coisas." De forma mais contida, Marcelo Rebelo de Sousa (RTP1, 25.01.2009) afirmou: "isto é mau para Portugal".

Na semana seguinte, Vasco Pulido Valente retomou a mesma linha de comentário, tecendo críticas contra a conduta do Primeiro-Ministro: "esta linguagem é uma linguagem absolutamente inaceitável em democracia. Não houve ditadores nestes últimos 150 anos que não tivessem usado isto. Estaline, Hitler, Mussolini, Franco, Salazar (...). Transformar um assunto destes num duelo entre o bem e o mal mostra bem o caráter do Sr. Primeiro-Ministro. Não imagino nenhum Primeiro-Ministro que 0 antecedeu, ou europeu, a fazer isto" (TVI, 30.01.2009).

Paralelamente, os comentadores posicionaram-se também contra a conduta da justiça. 0 jurista e ex-Bastonário da Ordem dos Advogados Rogério Alves afirmou (TVI, 29.03.2009): “Compete ao Ministério Público denunciar a situação - pressões para arquivamento - e investigá-la. (...). Esta bruma sobre bruma, névoa sobre névoa, é o Ministério Público quem tem de dissipar. Neste momento começa a ser um imperativo patriótico ter de a dissipar". De forma ainda mais incisiva, Miguel Sousa Tavares (TVI, 14.05.2009) tomou uma clara posição contra o Ministério Público: "espero que o objetivo final não seja criar a ideia nas pessoas de que cada vez que há um processo que mete políticos, que há pressões sobre os magistrados, porque isso poderia servir como pretexto para que os magistrados do Ministério Público exigissem ainda mais autonomia. (...). 0 Ministro da Justiça não tem quaisquer poderes sobre o funcionamento do Ministério Público. Eu espero que não seja isso". 
Os dados revelam-nos que, contrariamente aos media noticiosos, que abordaram o caso com cautela, os comentadores foram muito críticos e adotaram uma postura maioritariamente conflitual, produzindo opiniões com níveis de animosidade elevada em detrimento da discussão política. 0 esclarecimento da sociedade civil acerca das políticas tomadas pelos governantes que elegeu não foi prioritário.

\section{0 caso Face Oculta e as Escutas}

0 processo Face Oculta foi noticiado pela primeira vez no fim de outubro de 2009 e a leitura da sentença ocorreu em setembro de 2014. Neste processo todos os arguidos foram condenados, tendo sido muito comentadas as penas de prisão atribuídas aos envolvidos. Num primeiro nível, a noticiabilidade do caso decorreu do envolvimento de figuras cimeiras da administração pública e privada em Portugal, mas o foco central foi o envolvimento de uma figura muito próxima do Primeiro-Ministro em funções, Armando Vara, à época vice-presidente do BCP e ex-ministro do anterior governo de José Sócrates. As acusações relacionavam-se com lavagem de dinheiro, corrupção política e evasão fiscal. Algumas semanas depois de se conhecer este caso, ficou-se a saber da existência de escutas telefónicas entre Armando Vara e José Sócrates, que fizeram emergir de dentro do processo Face Oculta o "caso das Escutas", relacionado com um alegado conluio orquestrado pelo Primeiro-Ministro para a compra da TVI pela PT, constituindo esta conduta um possível crime de atentado contra o estado de direito. Na base desta intenção estaria o objetivo de pôr termo a uma campanha jornalística negativa e prejudicial para o Primeiro-Ministro, bem ilustrada pela cobertura do processo Freeport pela TVI. Este caso trouxe novamente para o espaço público discussões sobre o segredo de justiça.

0 Face Oculta emergiu a 29 de outubro de 2009 e é nos últimos meses desse ano que atinge maior atenção mediática no noticiário de prime-time das televisões generalistas portuguesas. Enquanto nos últimos meses de 2009 foram emitidas 356 peças sobre 0 caso, ao longo dos 12 meses do ano seguinte a cobertura jornalística diminuiu de forma significativa para 213 peças.

Novamente, como antecâmara da análise da opinião sobre o caso Face Oculta, e de modo a podermos relacionar as narrativas do comentário e noticiosa, começamos por identificar os temas principais, os atores mais referidos e o tom dominante nas peças jornalísticas. Em 2009, em pouco mais de dois meses, foram emitidas 356 peças: 123 na RTP1, 128 na SIC e 105 na TVI. Em termos de temas principais, destacam-se as "escutas" a envolver o Primeiro-Ministro José Sócrates (100 peças), seguidas de peças sobre as "investigações e buscas" (56 peças). Em termos de atores, Armando Vara, enquanto ex-membro do governo, foi a personalidade mais evocada (69 vezes), seguida do Primeiro-Ministro José Sócrates (42 vezes) e do empresário Manuel Godinho (42 vezes). A maioria das peças noticiosas oscilou entre 0 tom negativo (147) e 0 tom neutro (129 vezes). No cruzamento das variáveis "tema" e "ator", constatamos que Armando Vara foi citado principalmente no início do caso, quando as questões dominantes eram "investigações e buscas" (24 vezes) e "suspensão de funções" (16 vezes). 0 fato de os suspeitos se manterem nos seus cargos foi objeto de ampla cobertura noticiosa. 0 tom maioritariamente associado a Armando Vara foi o equilibrado (27 vezes), seguido do tendencialmente negativo (25 vezes). No caso de José Sócrates, a segunda personalidade mais evocada no 
caso Face Oculta, o cruzamento das variáveis permite-nos constatar que o PM foi primordialmente associado ao tema das escutas (30 vezes). Este dado evidencia-se mais se tivermos em conta que o segundo tema que Ihe foi associado, "declarações", surgiu apenas em sete peças. A cobertura de José Sócrates foi tendencialmente negativa (23 vezes).

De entre 356 peças emitidas em 2009, encontramos 11 comentários: seis na RTP1, três na SIC e dois na TVI, num total de uma hora, três minutos e três segundos de opiniões emitidas. A desproporção do número de comentários face ao total das peças sobre 0 assunto explica-se pelo facto de a maioria desses comentários ocorrer dentro de espaços de opinião de periodicidade semanal fixa. Deste modo, os dados adquirem uma leitura distinta se em vez de os enquadrarmos em termos de dias, os perspetivarmos em termos de semanas, nomeadamente as 10 semanas entre 0 espoletar do caso, no fim de outubro, e os últimos dias do mês de dezembro. De entre todos os comentadores, Marcelo Rebelo de Sousa (na RTP1) foi o que mais abordou o tema (seis vezes), seguido de Miguel Sousa Tavares (TVI) com dois comentários.

Nesse ano de 2009, a SIC não tinha comentadores fixos no noticiário da noite e, por isso, o caso foi tratado por três colaboradores distintos que fazem parte da carteira de comentadores do canal e cuja presença no Jornal da Noite decorre dos temas em agenda. Deste modo, no dia em que se ficou a saber das buscas a várias empresas, a SIC inaugurou o comentário sobre o Face Oculta com o jornalista da estação José Gomes Ferreira. Cinco dias depois, a 4 de novembro, a componente política tornou-se 0 ângulo dominante, e a inaugurá-la esteve Ricardo Costa, comentador da SIC, ex-jornalista da estação e diretor do Expresso, semanário do mesmo grupo proprietário do canal de televisão; duas semanas depois (a 24 de novembro), 0 ângulo privilegiado foi o jurídico, num comentário de Luís Filipe Carvalho, advogado e comentador do canal. Na TVI, Miguel Sousa Tavares comentou este caso durante duas semanas consecutivas e apenas regressou ao tema quando as "escutas" emergiram na terceira semana de novembro.

De que modo é que os comentadores abordaram o caso Face Oculta? Em primeiro lugar, importa analisar os comentários em termos de "temas", "atores" e "tom", para, de seguida, extrairmos ilações sobre a relação entre os espaços de comentário e noticioso. Em sede do comentário há dois grandes temas que se destacam em dois momentos distintos da evolução do caso nos media. Nas primeiras semanas, foi o tema "crimes de corrupção" (quatro comentários) que dominou, e, a partir de meados do mês de novembro, a questão central passou a ser as "escutas" (seis comentários). Inicialmente, a questão dominante nos comentários foi o ilícito que estava na base da investigação, o crime de corrupção. As análises debruçaram-se sobre as relações entre o poder político e o tecido empresarial, a circulação de lugares de um setor para o outro, e a cadeia de favores e favorecimentos entre ambos os setores. Neste âmbito, emergiu um debate sobre possíveis impulsos legislativos que os comentários repudiaram pelo seu caráter reativo e casuístico, levando Ricardo Costa a afirmar (SIC: 04.11.2009): "quase que aposto que vão cair na fúria legislativa de legislar contra a corrupção. É um erro".

Ainda na primeira fase do processo, os comentadores debateram a (não) suspensão de funções dos principais envolvidos, o ex-ministro Armando Vara e José Penedos, considerando que a saída de ambos seria benéfica para a imagem dos 
cargos de poder e das instituições que lideravam, tal como ficou evidente nas palavras de José Gomes Ferreira (SIC: 30.10.2009): "ninguém pode ser demitido nestas circunstâncias, mas eu pergunto o seguinte ao Governador do Banco de Portugal, ao Ministro da Economia, aos presidentes destas empresas: (...) olhem para si próprios, olhem para o país e perguntem-se se isto pode continuar assim? Se estas pessoas podem continuar nos lugares? (...) Sintam o país e digam se é possível sustentar esta situação de desconfiança em que o país mergulhou na sequência do que é sabido?" Na mesma linha, Marcelo Rebelo de Sousa afirmou (RTP1: 01.11.2009): "(...) a pessoa não se deve sentir muito à-vontade, mesmo que não tenha nada a ver, em estar a ser julgado ou investigado como arguido num processo que diga respeito a corrupção. Visto de fora dá-me a sensação que os padrões éticos têm baixado muito ultimamente. (...) Se as pessoas estão constituídas arguidas devem suspender-se das funções (.....). A sensação é que as pessoas vão ficando, como se ser arguido fosse a coisa mais natural do mundo. Exercem as suas funções esquecendo que isso repercute negativamente nos cargos que desempenham".

Numa segunda fase do caso, a partir da segunda metade do mês de novembro, o caso das "escutas" tornou-se o tema dominante e relegou o Face Oculta para segundo plano das atenções, como notou Marcelo Rebelo de Sousa (RTP1: 15.11.2009): "Isto das escutas afastou do essencial, que é a Face Oculta". Nesta segunda parte da história, os atores principais foram o Procurador-Geral da República António Pinto Monteiro (destacado em sete comentários), o Primeiro-Ministro José Sócrates (destacado em 6 comentários), e o ex-ministro de José Sócrates e arguido no processo Face Oculta Armando Vara (destacado em cinco comentários). 0 tom dos comentários foi maioritariamente negativo (sete comentários), acompanhado em menor grau por comentários equilibrados (quatro comentários), encontrando-se num mesmo comentário apreciações negativas atenuadas por outras positivas.

No cruzamento das variáveis, António Pinto Monteiro surgiu associado às escutas num tom dominantemente negativo (cinco em sete comentários). Por sua vez, José Sócrates viu-se associado aos dois grandes temas, salientando-se as escutas por ter sido essa também a questão dominante na análise ao caso: quatro apreciações negativas e duas equilibradas. 0 Primeiro-Ministro surgiu de forma latente como 0 grande ator do Face Oculta, mas a partir do momento em que emergiu o tema das escutas foi trazido para o centro do comentário. Interpretações sobre as conversas gravadas, a legalidade das escutas, o segredo de justiça e a revelação do conteúdo nos media foram temas apenas superados pela análise à conduta do Procurador Geral da República, António Pinto Monteiro, e à forma como geriu o processo.

Deste modo, podemos afirmar que o caso Face Oculta foi abordado pelos comentadores principalmente pelo ângulo da conduta e das consequências políticas para os atores mais referidos nos comentadores: o Primeiro-Ministro e o Procurador-Geral da República. 0 primeiro por insistir nas teses da cabala e o segundo pela forma como demorou a decidir sobre a legalidade das escutas e por ter comentado publicamente o processo, ficando no ar sugestões de benefícios ao governo e de proteção ao PM durante o período de campanha eleitoral. As palavras de Marcelo Rebelo de Sousa são bem ilustrativas sobre ambos (RTP1: 22.11.2009): "0 Procurador atuou duma forma tão atabalhoada, com tantos pontapés no direito, na maneira como agiu, que não acabou por credibilizar e acabou por não dar força à decisão. 
(...) Eu penso que ele geriu demasiado esta matéria em termos políticos. Certamente com bons propósitos, mas não servindo a força da sua posição e no fundo isto é o retrato em que se encontra o Procurador. De um lado o Ministério Público não se revê nele. Do outro lado o poder político dá-Ihe confiança, mas diz o homem não manda no Ministério Público. Ee exatamente isto o que se passa. Ele não manda no MP e do outro lado não tem a confiança de uma parte substancial do MP, daí esta gestão com muitas complicações. (...). A ideia de querer criar uma tese da conspiração é a tese que levou sempre o Sr. Berlusconi a dizer sempre isso da justiça (...)." No sentido oposto de Marcelo, Miguel Sousa Tavares (TVI: 26.11.2009) insurgiu-se contra os que acusavam José Sócrates de estar a preparar um crime contra o estado de direito: "Como é que uma suposta compra da TVI pela PT pode ser um crime contra o estado de direito? Vamos admitir que de facto José Sócrates queria que a TVI fosse comprada para acabar com o Jornal de Sexta; daí para se dar 0 salto de crime contra o estado de direito parece-me demasiado fácil."

Em termos de relações entre as componentes informativa e de opinião, verificamos que em ambos os espaços a questão das escutas foi o tópico mais debatido. Enquanto nas notícias este tema foi secundado pelas investigações e pelas buscas judiciais, na opinião esteve ligado ao crime da corrupção (que em termos informativos foi o quinto tema mais registado na cobertura do caso Face Oculta). Assinalamos também algumas diferenças nos atores mais evidenciados pelos comentadores. Estes centraram-se prioritariamente nas personalidades de maior poder real e simbólico citadas nas peças: José Sócrates e António Pinto Monteiro, Primeiro-Ministro e Procurador-Geral da República. As personalidades que estavam a ser investigadas e que foram mais focadas nas notícias - Armando Vara, José Penedos e Manuel Godinho - tiveram menor interesses para os comentadores. Por sua vez, o Procurador Geral da República surgiu em quarto lugar nas notícias (referido 29 vezes), atrás de Manuel Godinho, o terceiro ator mais referenciado (42 vezes).

Num primeiro nível de contiguidade confirma-se a relação entre as notícias e as opiniões. A agenda do comentário é cada vez mais presentificada e os comentadores partem dos acontecimentos do dia e da semana para analisarem determinados temas. Para lá desta dimensão, o que se verificou em sede do comentário foi a criação de uma narrativa própria sobre o caso, que se traduziu em muito mais do que num destaque distinto a certos temas e atores.

Os comentadores ordenam e destacam os factos à sua maneira e constroem uma versão dos acontecimentos em cuja narração encontramos o toque pessoal do seu autor. Para os comentadores esta foi uma história sobre a luta de poder dentro das, e entre, as esferas política e judicial, personificada pelas mais altas instâncias. Como interface do e de poder, a narrativa do comentário sobre o caso Face Oculta refletiu bem a relação dos comentadores com as esferas de privilégio de onde eles próprios são provenientes.

Tradicionalmente, o comentário foi instituído como um espaço de interpretação e esclarecimento de causas, contextos e consequências, complementando, assim, as notícias naquilo que pelas suas características não podiam oferecer ao auditório. Deste modo, importa saber como é que os comentadores debateram a questão e perceber se a narrativa distinta produzida pelos comentários sobre o caso Face 
Oculta contribuiu para o esclarecimento público. A variável "estilo" pretende, assim, definir a estrutura da argumentação do comentário, ou seja, a forma como as ideias foram apresentadas. Em termos de estratégia retórica, a maioria dos comentadores tomou uma posição clara (sete comentários), nomeadamente contra as suspeitas de corrupção: "Tem que se tirar ilações. Isto não pode mesmo ficar assim", considerou José Gomes Ferreira (SIC: 30.10 .2009 ), enquanto Marcelo definiu este como um "caso muito grave" (RTP1: 01.11.2009). A conduta dos arguidos envolvidos e, principalmente, a forma como os principais protagonistas conduziram 0 caso foi outro ângulo sobre o qual os comentadores se posicionaram claramente: "Eu acho que a divulgação é corrigir um erro com outro erro. 0 Procurador é cada cavadela, sua minhoca" (RTP1: 29.11.2009) e "os magistrados têm de ter a noção que não podem falar" voltou a afirmar Marcelo (RTP1: 13.12.2009), enquanto para Miguel Sousa Tavares (TVI: 03.12.2009) "o Procurador-Geral da República deveria ter despachado imediatamente" e "não é aceitável que um líder político faça um aproveitamento político".

A distinção analítica nem sempre foi fácil e simples e, por vezes, como estratégia argumentativa para justificar a tomada de posição, os comentadores fizeram uma introdução mais contextualizadora. Todavia, foi possível identificar um estilo dominante que nos permite afirmar que a maioria dos comentários foram críticos, tendo a opinião sido principalmente orientada contra a atuação dos que entenderam ser os principais protagonistas. Os comentadores reproduziram, assim, no espaço opinião os conflitos entre os campos envolvidos no caso. Com muito menor expressão encontramos comentários que se detivessem na explicação do contexto e nas consequências deste caso tão intrincado, bem como no esclarecimento das relações ou nas consequências de determinadas condutas.

\section{PARA QUEM FALAM OS COMENTADORES?}

Contribuir para o esclarecimento público e a formação da opinião são dois atributos fundamentais do jornalismo ocidental e que estão na base da visão normativa da imprensa enquanto instituição basilar dos regimes democráticos. Nesta perspetiva, os media desempenham uma função primordial de informar e esclarecer os cidadãos, bem como de organizar o debate público, num processo de ativação da atenção e de participação na formação da opinião pública que inclui os comentários. Deste modo, para além das dimensões já analisadas, importa conhecer a quem é que os comentadores se dirigem e como é que se posicionam nesse debate.

Os programas televisivos, nomeadamente os noticiários de prime-time, são feitos para serem vistos por um vasto auditório, destinatário da emissão. 0 contrato comunicativo entre locutor e interlocutor, que é o comentador, inclui, assim, o reconhecimento de que a conversação em estúdio se dirige aos espetadores que visionam o programa. No entanto, podem existir outros destinatários indiretos dentro do grupo dos alocutários oficialmente instituídos, o que torna o quadro dos destinatários mais complexo. Ou seja, o destinatário diretamente convocado pelos indícios de alocução pode ser um destinatário secundário, e o destinatário indireto 0 alvo privilegiado. Devemos então pensar numa "hierarquia de destinatários" (Kerbrat-Orecchioni:1990: 90) em lugar de tentarmos decidir rigidamente sobre o estatuto direto ou indireto de um alocutário. 
De modo a conhecermos a forma como os comentadores entendem e usam o seu poder no espaço público, identificámos marcas discursivas que permitem sinalizar diferentes níveis de destinatários das opiniões. Para este objetivo do trabalho, e tendo em conta a reduzida dimensão do corpus de análise, agregámos os 43 comentários emitidos sobre os casos Freeporte Face Oculta e analisámo-los em conjunto.

Se pensarmos num eixo contínuo em que encontramos, num extremo, comentários que são pouco mais do que uma conversa com e para as elites, e, no outro extremo, opiniões que são diretamente proferidas para os cidadãos em geral e a pensar no seu esclarecimento, verificamos que a maioria das opiniões sobre os casos Freeport e Face Oculta é o resultado de um jogo de equilíbrios delicados entre ser e parecer um insider ou querer simular uma distância dos círculos do poder, posicionando-se discursivamente como um outsider, ou seja, como a maioria do auditório dos noticiários dos canais de televisão generalista.

A análise permite concluir que a maioria dos comentadores se posiciona no debate público como players com capacidade de influenciar o desenvolvimento dos assuntos que estão em agenda, assumindo um papel de conselheiros das elites políticas, dando-Ihes instruções ou propondo sugestões aos decisores políticos (Nimmo \& Combs: 1992: 26). Nestes casos, os comentadores falam com as elites e para as elites, tal como fez José Gomes Ferreira a propósito do caso Face Oculta: “Ninguém pode ser demitido nestas circunstâncias, mas eu pergunto o seguinte: Sr. Presidente do BCP, Sr. Governador do Banco de Portugal, Sr. Presidente da Comissão de Mercados de Valores, Sr. Ministro das Finanças, Sr. Ministro da Economia, olhem para si próprios, olhem para o país e perguntem-se se isto pode continuar assim? Se estas pessoas podem continuar nos lugares? (...) Faço até o convite a um pequeno exercício. Sintam o país e digam se é possível sustentar esta situação de desconfiança em que o país mergulhou na sequência do que é sabido? Tem que se tirar ilações. Isto não pode mesmo ficar assim" (SIC: 30.10.2009).

Rogério Alves fez algo semelhante ao comentar o caso Freeport(TVl: 29.03.2009): "As autoridades não podem fingir que não conhecem as provas. 0 Ministério Público tem aqui uma obrigação especial de imprimir aceleração a este processo e chegar rapidamente a uma conclusão. (...) Há um dever quase patriótico de concluir esta investigação". António José Teixeira também o fez ao analisar o caso Freeport (SIC: 31.03.2009): "Por que não José Sócrates tomar a iniciativa e pedir para ser ouvido? Nesta altura julgo que há justificações mais do que suficientes sem que isso queira dizer obviamente qualquer afirmação de culpabilidade ou envolvimento, mas acho que nesta altura seria importante". E Marcelo Rebelo de Sousa, ainda sobre o mesmo tema, vaticinou (RTP1: 01.02.2009): "A investigação deve avançar. Portanto, os investigadores em vez de darem tantas entrevistas, devem trabalhar. 0 importante é que a Cândida Almeida chegue rapidamente a conclusões (...) e que se apure rapidamente isto."

Nenhum destes comentadores ocupa um cargo formal de autoridade no círculo da elite, mas movem-se dentro dela, têm acesso a informação privilegiada e sentem-se à vontade para interpelarem essas elites. Neste âmbito encontramos ainda segmentos em que os comentadores se posicionam de forma ambígua, colocando-se simultaneamente como insidere outsider da esfera de poder. Ao mesmo tempo que assumem uma posição de representantes e porta-vozes da opinião pública, utilizam esse estatuto para reclamarem determinado comportamento das elites. Quando utilizam 
esta estratégia, os comentadores escudam-se nos portugueses para reforçarem a sua posição, tal como estes excertos ilustram: "0 importante é que a Cândida Almeida chegue rapidamente a conclusões (...) e que se apure rapidamente isto. É isso que os portugueses querem" (Marcelo Rebelo de Sousa, RTP1:01.02.2009). "Eu acho que José Sócrates deve falar, porque as pessoas não percebem bem os meandros daquela história e o que veem é aquela excitação, aquele nervosismo e aquele ar agressivo" (António José Teixeira, SIC: 29.01.2009). Nestes casos, em nome dos outsiders, os comentadores falam para círculos de dentro do poder. Esta estratégia discursiva funciona igualmente como meio de pressão para determinada ação que pretendem.

Neste jogo de equilíbrios discursivos entre estar dentro e estar fora, é ainda visível uma variação de posicionamento nos comentários de Marcelo Rebelo de Sousa, que constrói discursivamente laços com o auditório, expressando-se como se também ele fosse um elemento externo ao círculo das elites: "Visto de fora dá-me a sensação que os padrões éticos têm baixado muito ultimamente" (RTP1: 01.11.2009). Esta estratégia é também seguida por Miguel Sousa Tavares (TVI: 14.05.2009): “Espero que 0 objetivo final não seja criar a ideia nas pessoas de que cada vez que há um processo que mete políticos, há pressões sobre os magistrados. Por que isso poderia significar servir como pretexto para que os magistrados do Ministério Público exigissem ainda mais autonomia. Estes funcionam num sistema que, a meu ver, é em roda-livre, sem controlo efetivo. Não há contrapoder para o Ministério Público. 0 Ministério da Justiça não tem quaisquer poderes sobre o funcionamento do Ministério Público. Eu espero que não seja isso".

Por outro lado, em menor grau encontramos os comentários cujo foco dominante é o destinatário outsider. Os comentários de Rogério Alves nos noticiários são um bom exemplo deste posicionamento: "No fundo o que é uma carta rogatória?" (SIC: 29.01.2009). Dois meses depois, na TVI, encontramos o mesmo registo por parte deste comentador: "Compreendo que para as pessoas isto seja um bocadinho difícil de compreender. Vamos lá ver..." e mais à frente no mesmo segmento termina dizendo: "Percebo que para as pessoas isto soe um bocadinho estranho, mas estas são as regras do processo penal. Estas são as regras do estado de direito" (TVI: 29.03.2009). Marcelo Rebelo de Sousa também utiliza nos seus comentários o artifício do pedagogo e um tom professoral: "os portugueses têm de pensar que isso faz parte da lógica da democracia; nas ditaduras não há, mas nas democracias, sim" (RTP1: 01.02.2009). E inclui o espetador na conversa, reconhecendo a sua presença do outro lado da câmara: "Perguntas que os portugueses fazem e que eu vou tentar agora seriá-las" (RTP1: 05.05.2009), "Respondendo aos portugueses..." (RTP1: 24.05.2009). Quando os comentadores assumem esta função pedagógica, o espaço de opinião torna-se uma aula e os espetadores tornam-se estudantes que é preciso esclarecer e ajudar a compreender as questões em debate. Nestes momentos, os comentadores fazem a mediação entre um conhecimento especializado e partilhado entre insiders, as elites, e outsiders, os cidadãos em geral.

\section{Notas Finais}

O espaço de opinião é um local de poder que confere e reforça o estatuto de quem nele participa (Nimmo \& Combs: 1994; Figueiras: 2009; Jacobs \& Townsley: 2011). 0 impacto dos comentários deve, no entanto, ser perspetivado em articulação com 
a projeção social do meio onde os comentadores colaboram e do programa em que participam. Nos canais de televisão no cabo as audiências são mais fragmentadas e reduzidas e a diversidade e polarização de opiniões é mais acentuada. Por sua vez, apesar de atingirem um número muito mais vasto de espetadores, os comentários emitidos nos canais generalistas tendem a ter uma amplitude de opiniões mais reduzida.

No âmbito dos noticiários das televisões generalistas, o estudo que aqui se apresentou sobre dois dos casos de corrupção de maior projeção mediática nos últimos anos em Portugal - os casos Freeport e Face Oculta - tal como referido, teve dois grandes objetivos: (1) relacionar as narrativas jornalísticas e dos comentários sobre os dois casos referidos e (2) conhecer a forma como os comentadores se posicionaram no debate público e como entenderam a sua função no processo comunicativo democrático.

Da análise efetuada, constatámos que o espaço de opinião foi menos centrado na substância das questões, menos perspetivado como um lugar de esclarecimento e interpretação dos casos, tendo sido prioritariamente utilizado para os comentadores assumirem uma posição em relação ao que definiram como o conflito central e os protagonistas e antagonistas destas histórias.

Num discurso crítico envolto em elevada dramaticidade, na agenda dos interesses dos comentadores encontrámos uma menor presença de dimensões estruturais do problema da corrupção, tendo antes estado no centro da sua narrativa o desempenho das partes envolvidas. Em linha com uma conceção goffmaniana (1993), e colocando-se no papel de plateia privilegiada do poder em cena, os comentadores concentraram as suas atenções nas dimensões performativas dos protagonistas e antagonistas, avaliando o que consideraram ser a apresentação "certa" do "Eu" como garantia da credibilidade dos atores centrais de ambos os casos: o Primeiro-Ministro José Sócrates, o Procurador-Geral da República António Pinto Monteiro e os Magistrados do Ministério Público. Para os comentadores estas duas histórias foram mais sobre estratégia política dos atores e das instituições envolvidas do que sobre 0 crime da corrupção.

Os comentadores adotaram uma postura conflitual, consubstanciada em tons negativos sobre 0 que entenderam ser o comportamento desadequado dos atores envolvidos. A narrativa do comentário foi muito crítica. Em 43 comentários, 20 foram negativos, indo estes resultados ao encontro de outros estudos já realizados sobre o comentário político em Portugal (Figueiras, 2009). Interessante foi verificar que esse criticismo não foi acompanhado pela narrativa jornalística, ao contrário do que os trabalhos sobre a cobertura jornalística da política revelam há anos (Siegelmann \& Bullock: 1991; Graber, McQuail \& Norris: 2008; Cunha: 2012). Nos dois casos analisados, em 1045 peças noticiosas, 623 foram neutras e "apenas" 278 tendencialmente negativas.

Sabemos que os espaços de opinião têm subjacente a ideia de que o comentário reflete uma posição pessoal. No entanto, sabemos também que o comentário, para além de refletir as lógicas do campo de origem do comentador, é, igualmente, um produto do meio que o convidou para expressar as suas opiniões. A escolha de determinadas individualidades (cujos posicionamentos ideológicos são sobejamente conhecidos) em detrimento de outras é feita por um conjunto de motivos, entre os quais se incluem um determinado entendimento da sociedade portuguesa e uma 
determinada abordagem aos temas em consonância com um alinhamento editorial macro do meio de comunicação.

Na conjugação dos elementos elencados, colocamos a hipótese de que para além dos usos estratégicos dos comentários nos noticiários da noite já referidos no início da análise dos casos Freeporte Face Oculta, a narrativa jornalística se escudou nos comentadores para que determinadas avaliações pudessem ser emitidas em sede dos noticiários da noite. Libertos dos constrangimentos da produção noticiosa, de certas cautelas e do jornalismo dependente do discurso oficial (patente, inclusive, no predomínio do tema "declarações"), colocamos também a hipótese de os comentadores terem dito aquilo que os jornalistas não tiveram condições para dizer. Os segmentos dos programas de comentário dos canais de cabo selecionados para passarem nos noticiários generalistas permitem-nos considerar como válida esta possibilidade.

Numa peça de 2:38' foram sintetizadas as opiniões dos comentadores residentes da Quadratura do Círculo (SIC Notícias: 05.02.2009), da qual citamos um pequeno excerto de José Pacheco Pereira: "um Primeiro-Ministro não pode dizer isto sem dizer mais alguma coisa. Estou a ver um homem que tem um comportamento, face à verdade, elástico" e de António Costa: "há uma sanha de ódio de um setor político em Portugal, da direita portuguesa, relativamente ao atual Primeiro-Ministro". Por sua vez, numa peça de 1:35', o noticiário da TVI (21.04.2009) passou uma peça com excertos das opiniões dos comentadores do programa "A Torto e a Direito" (TVI24), onde Fernanda Câncio diz: "Aquilo que o Presidente dos Magistrados fez agora ao dizer que quer recorrer ao Presidente da República foi uma coisa que é realmente muitíssimo preocupante e que põe em causa, como aliás o Vasco Pulido Valente disse ontem na TVI, os pilares do Estado de Direito, que é a questão da separação entre a política e a justiça"; segue-se-Ihe Francisco José Viegas: "ou houve pressões ou não houve pressões. É que se houve pressões do dr. Lopes da Mota sobre os magistrados, o dr. Lopes da Mota deve ser removido do Eurojust, porque não é digno de um estado democrático. Se 0 dr. Alberto da Costa pediu ao dr. Lopes da Mota para pressionar os magistrados é ainda muto mais grave". Este conjunto de vozes sintetizam as duas grandes perspetivas vinculadas aos interesses dos partidos que alternadamente têm ocupado o poder em Portugal, os chamados "Partidos do Centro", e que mantêm uma cumplicidade com os grupos de interesse representados nos espaços de opinião generalista.

A validade desta hipótese é reforçada e complementada pelo perfil dos comentadores que se pronunciaram sobre os dois casos. A grande maioria dos comentadores é proveniente dos campos sociais diretamente envolvidos na história: político, judicial e jornalístico. Os dois primeiros discursos assumem o estatuto de vozes da autoridade, ou de especialistas, cuja legitimidade advém do conhecimento direto que têm dos campos sociais comentados. No caso dos jornalistas, a sua especialização em matéria de política decorre, não do exercício dessa atividade, mas da sua profissão, que os coloca numa posição privilegiada na construção social dos temas públicos.

Outra nota conclusiva que gostaríamos de salientar é que a opinião nos noticiários televisivos reproduziu práticas, representações e lutas das esferas implicadas nos casos em análise. Os espaços de opinião revelaram ser uma extensão de cada uma dessas esferas, o que significa que os conflitos e as lutas internas den- 
tro de cada campo, e entre os vários campos, foram transpostos para o espaço de comentário onde ficaram plasmadas as relações de força (preservação e transformação) dentro de cada esfera e entre os vários campos. Verificamos, assim, que a definição dos problemas, as interpretações causais, as avaliações morais e/ou recomendações foram construídas a partir do establishment, cujo poder é reforçado pela possibilidade de gerir a interpretação do que está a acontecer. Neste sentido, na esteira de John B. Thompson (2000), constatamos que a análise da narrativa do comentário se revelou um local privilegiado para identificar e compreender como as lutas sociais de poder são travadas no espaço público.

Esta questão liga-se ainda ao outro grande objetivo deste trabalho: conhecer a forma como os comentadores se posicionaram no debate público sobre o tema e como entenderam a sua função no processo comunicativo democrático. Tal como vimos, a esmagadora maioria dos comentários foi feita para dentro dos círculos das elites dirigentes, dos quais os comentadores fazem parte. Foram proferidos para a elite em geral e também para os visados nos casos. Decorrentemente, registámos uma presença relativamente reduzida de opiniões cujo destinatário primeiro fossem os outsiders do sistema, o público em geral.

Nem sempre foi fácil identificar os destinatários. Se a dificuldade decorre em parte da ambiguidade discursiva dos comentadores, julgamos que decorre também das identidades, em certa medida antagónicas, do espaço de opinião e da televisão generalista. A maioria dos comentadores que se pronunciou sobre os dois casos em análise formou-se na imprensa de referência portuguesa. Este tipo de imprensa dirige-se a uma plateia formada por uma pequena elite, principalmente urbana, escolarizada e politicamente ativa, significando também que os jornais e as suas audiências estão envolvidos num processo horizontal de debate e negociação entre as suas fações de elite (Hallin \& Mancini: 2004). No entanto, o jornalismo televisivo em canais generalistas trabalha para o grande público, acomoda uma ampla gama de interesses não necessariamente comprometidos com o mundo político. Isto significa que os espaços de comentário dos noticiários televisivos de prime-time articulam duas lógicas nem sempre de fácil harmonização. Ainda que alguns comentadores tenham tido em conta as características da televisão generalista, e articulado o processo horizontal de comunicação intra, e interelite, e 0 vertical dirigido ao público em geral, o estudo de ambos os casos permitiu verificar que o espaço de opinião continua a subsistir como um setor dominado pelas elites dirigentes na sociedade portuguesa, que comunica principalmente para si própria e que se mantém com uma capacidade elevada de imunidade à evolução do contexto social e mediático.

A dimensão do corpus de análise estudado é reduzida para podermos fazer extrapolações e generalizações sobre o espaço de opinião, mas não deixa de oferecer um conjunto de pistas relevantes para serem aprofundadas em outras investigações futuras sobre os usos estratégicos do espaço de opinião em Portugal.

\section{BibliogRAFIA}

Blankenburg, E. (2002). From political Clientelism to Outrighy Corruption - The Rise of the Scandal Industry In: Kotkin, S. \& Sajó, A. Political Corruption in Transition: a Sceptic's Handbook. Budapest: Central European University Press. 
Bourdieu, P. (1989). O Poder. Lisboa: Difel.

Bourdieu, P. (1997). Sobre a Televisão. Oeiras: Celta Editora.

Cunha, I. (2012). Partidos, Candidatos e Temas nas Legislativas In: Figueiras, R. (ed.) Os Media e as Eleições Europeias, Legislativas e Autárquicas de 2009. Lisboa: UC Editora. Cunha, I. (2014). Visibilidade da cobertura jornalística da corrupção política e indicadores de opinião pública. In: Cunha, I. F. \& Serrano, E. (coords.). Cobertura Jornalística da Corrupção Política (pp. 371-419). Lisboa: Alêtheia.

Entman, R. (2003). Cascading Activation:Contesting the White House's Frame After 9/11, Political Communication 20: 415-432.

Figueiras, R. (2005). Os Comentadores e os Media. Os Autores das Colunas de Opinião. Lisboa: Livros Horizonte.

Figueiras, F. (2007). Os Comentadores na Imprensa Portuguesa. In: Cunha, I.F. (coord.) Jornalismo e Democracia. Lisboa: Paulus Editora.

Figueiras, F. (2008). A Agenda dos Comentadores e a Política Nacional, Observatory - Journal of Communication $\left(O B S^{*}\right.$ ), vol.2 (2): 245- 262.

Figueiras, F. (2009). 0 Comentário Político e a Política do Comentário. Lisboa: Paulus Editora. Figueiras, F. (2011). Press Pundits and Portuguese Society. Journalism: Theory, Practice, and Criticism, vol. 12 (3): 317-333.

Figueiras, F. (2015). Democratic Culture and Public Opinion in Portugal. In: Figueiras, R., Espírito-Santo, P. e Cunha, I.F. (coords.). Democracy and Media at work: Pressure and Propaganda in Portugal and Brazil. Coimbra: Coimbra University Press.

Fraser, N. (2007). Transnationalizing the public sphere. On the legitimacy and efficacy of public opinion in a post-westphalian world. Theory, Culture \& Society, 4 (4): 7-30.

Goffman, E. (1993). A Apresentação do Eu na Vida de todos os Dias. Lisboa: Relógio d’ Água. Graber, D. , McQuail, D. \& Norris, P. (2008). The Politics of News. Washington: CQ Press. Granovetter, M. (2004). The Social Construction of Corruption. In:

(http://fsi-media.stanford.edu/evnts/4117/The_Social_Construction_of_Corruption_Oct04. pdf) (acedido 21/01/2015).

Habermas, J. (1984). Mudança Estrutural da Esfera Pública. Rio de Janeiro: Tempo Brasileiro. Hallin, D. \& Mancini, P. (2004). Comparing Media Systems: Three Models of Media and Politics. Cambridge: Cambridge University Press.

Heidenheimer, A.J. \& Johnston, M. (2002). Political Corruption. Concepts \& Contexts. New Jersey: Transaction Publishers.

International Transparency Corruption Global Report (2010). (http://www.transparency.org/ policy_research/surveys_indices/cpi) (acedido 31/01/2015).

Jacobs, R. \& Townsley, E. (2011). The Space of Opinion: Media Intellectuals and the Public Sphere, New York, Oxford University Press.

Kerbrat-Orecchioni, C. (1990). Les interactions verbales. Paris: Armand Colin. Luhmann, N. (1993). A Improbabilidade da Comunicação. Lisboa: Vega Passagens.

Mancini, P. (2009). Elogio della Iottizzazione. La via italiana al pluralismo. Bari: Laterza. Mazzoleni, G. e Schulz, W. (1999), Mediatization of Politics: A Challenge for Democracy? Political Communication 16 (3): 247-61.

Nimmo, D. \& Combs, J. E. (1992). The political pundits. New York: Praeger. 
Norris, P. (2000). The Virtuous Circle. Political Communications in Postindustrial Societies. Cambridge: Cambridge University Press.

Shea, D.H. (1999). All scandal politics is local: ethical lapses, the media, and congressional elections. The Harvard International Journal of Press Politics 4: 45-63.

Schudson, M. (1995). A esfera pública e os seus problemas. Reintroduzir a questão do Estado. Revista de Comunicação e Linguagens 21/22: 149-166.

Thompson, J. B. (1998). A Mídia e a Modernidade. Petrópolis: Editora Vozes.

Thompson, J.B. (2000). Political Scandal. Power and Visibility in the Media Age. Cambridge: Polity Press.

Tumber, H. \& Waisbor, S.R. (2004). Introduction: political scandals and media across democracies. American Behavioral Scientist, 47 (9):1143-1152.

\section{Quadro}

\begin{tabular}{|c|c|c|c|c|}
\hline & \multicolumn{2}{|l|}{ Freeport } & \multicolumn{2}{|c|}{ Face 0culta } \\
\hline & Comentador & Comentários & Comentador & Comentários \\
\hline \multirow[b]{2}{*}{ RTP 1} & $\begin{array}{l}\text { Eduardo Dâmaso, } \\
\text { Jornalista }\end{array}$ & 1 & $\begin{array}{l}\text { Marcelo Rebelo de Sousa, } \\
\text { Académico/Político/Jurista }\end{array}$ & 6 \\
\hline & $\begin{array}{l}\text { Marcelo Rebelo de Sousa, } \\
\text { Político/Jurista/ } \\
\text { Académico }\end{array}$ & 9 & & \\
\hline \multirow{9}{*}{ SIC } & António Costa, Político & 1 & $\begin{array}{l}\text { José Gomes Ferreira, } \\
\text { Jornalista }\end{array}$ & 1 \\
\hline & $\begin{array}{l}\text { António Lobo Xavier } \\
\text { Político/PLQS }\end{array}$ & 1 & $\begin{array}{l}\text { Luís Filipe Carvalho, } \\
\text { Jurista }\end{array}$ & 1 \\
\hline & $\begin{array}{l}\text { António José Teixeira, } \\
\text { Jornalista }\end{array}$ & 2 & Ricardo Costa, Jornalista & 1 \\
\hline & $\begin{array}{l}\text { Jorge Coelho, } \\
\text { Político/PLOS }\end{array}$ & 1 & & \\
\hline & $\begin{array}{l}\text { José Gomes Ferreira, } \\
\text { Jornalista }\end{array}$ & 1 & & \\
\hline & $\begin{array}{l}\text { José Pacheco Pereira, } \\
\text { Académico/Político }\end{array}$ & 1 & & \\
\hline & Luís Filipe Carvalho, Jurista & 1 & & \\
\hline & Ricardo Costa, Jornalista & 1 & & \\
\hline & Rogério Alves, Jurista & 1 & & \\
\hline \multirow{6}{*}{ TVI } & $\begin{array}{l}\text { Fernanda Câncio, } \\
\text { Jornalista }\end{array}$ & 1 & $\begin{array}{l}\text { Miguel Sousa Tavares, } \\
\text { Jornalista/Escritor }\end{array}$ & 2 \\
\hline & $\begin{array}{l}\text { Francisco José Viegas, } \\
\text { Escritor }\end{array}$ & 1 & & \\
\hline & $\begin{array}{l}\text { João Pereira Coutinho, } \\
\text { Jornalista-Academia }\end{array}$ & 1 & & \\
\hline & $\begin{array}{l}\text { Miguel Sousa Tavares, } \\
\text { Jornalista/Escritor }\end{array}$ & 3 & & \\
\hline & Rogério Alves, Jurista & 1 & & \\
\hline & $\begin{array}{l}\text { Vasco Pulido Valente, } \\
\text { Académico }\end{array}$ & 5 & & \\
\hline
\end{tabular}

